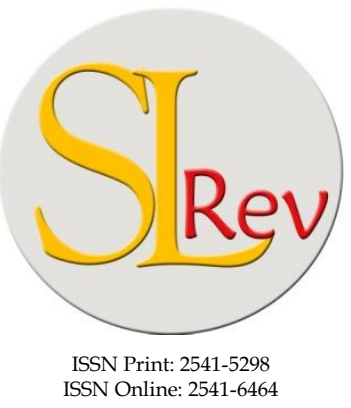

ISSN Online: 2541-6464

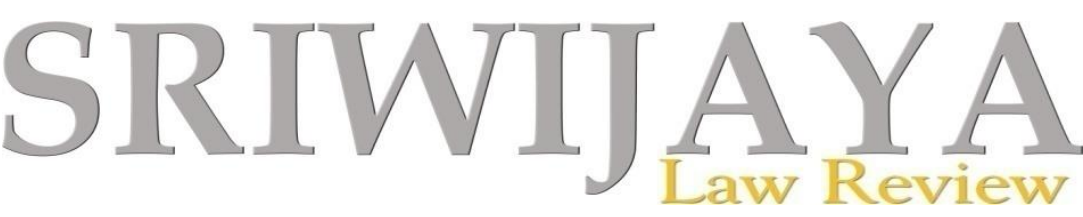

Editorial Office: Faculty of Law, Sriwijaya UniversityJalan Srijaya Negara, Palembang, South Sumatra 30139, Indonesia. Phone: +62711-580063Fax: +62711-581179

E-mail: sriwijayalawreview@unsri.ac.id| sriwijayalawreview@gmail.com

Website: http://journal.fh.unsri.ac.id/index.php/sriwijayalawreview

\title{
Tender Conspiracy Under KPPU Decision and Prohibition of Monopolistic Practices Act
}

\author{
Udin Silalahi $^{\mathrm{a}}$ and Priskilla Chrysentia ${ }^{\mathrm{a}}$
}

a Faculty of Law, Universitas Pelita Harapan, Tangerang, Indonesia.. E-mail: udin.silalahi@uph.edu

\begin{tabular}{ll}
\hline Article & Abstract \\
\hline $\begin{array}{l}\text { Keywords: } \\
\text { Competition Law; Pro- } \\
\text { hibition of Monopolistic } \\
\text { Practices; Tender } \\
\text { Conspiracy; KPPU. }\end{array}$ & $\begin{array}{l}\text { Tender conspiracy is one of the anti-competition acts prohibited under } \\
\text { Anfair Business Competition. As one of the violations which are almost } \\
\text { always injurious, tender conspiracy is only regulated by a rule of reasonable } \\
\text { approach giving an interpretation room of the consequences of the violation. } \\
\text { The tender conspiracy is also proven conducted by reported parties in the } \\
\text { case that it had been decided by KPPU, such as in the KPPU Decision }\end{array}$ \\
$\begin{array}{l}\text { Artikel History } \\
\text { Received: Jul 2, 2019; } \\
\text { Reviewed: Jan 16, 2020; } \\
\text { Accepted: Jan 31, 2020; } \\
\text { Published: Jan 31, 2020. }\end{array}$ & $\begin{array}{l}\text { rampant practices of tender conspiracy are how they regulate in the } \\
\text { applicable law and how KPPU decides on the practice of tender conspiracy } \\
\text { in the case concerned with the law. The aim is to examine the causes of the } \\
\text { governing it, as well as to review the KPPU's decision on real tender } \\
\text { conspiracy case. For this reason, this research is normative legal research } \\
\text { with qualitative analysis techniques on secondary data and uses the statute } \\
\text { approach, and case approaches. The results of the study indicate that Article } \\
\text { 22 is not sufficient yet to regulate the prohibition of tender conspiracy and } \\
\text { often leads to multi-interpretation. the KPPU decided that there is a } \\
\text { horizontal conspiracy among defendants in determining of the tender winner. }\end{array}$ \\
$\begin{array}{l}\text { DOI: } \\
\text { 10.28946/slrev.Vol4.Iss2. }\end{array}$ \\
347/pp91-108
\end{tabular}

(C)2020; This article is an Open Access Research distributed under the term of the Creative Commons Attribution License (https://Creativecommons.org/licences/by/4.0), which permits unrestricted use, distribution, and reproduction in any medium, provided the original works is properly cited.

\section{INTRODUCTION}

Business competition is one of the essential factors in running the economy of a country. It is one of the means to create innovation and quality improvement in business. Business actors always strive to give the best products or services offer both price and quality to attract the market, and most of all, to create a strong position to stay in the relevant market. Those who cannot offer exciting deals will inevitably lose its position in the market. The principle that applies is the survival of the fittest; the strong will eliminate the weak. ${ }^{1}$ It is in line with Adam

1 Arie Siswanto, Hukum Persaingan Usaha (Jakarta: Ghalia Indonesia, 2002). 
Smith's theory, who believes that in a competitive setting, resources are allocated to optimize consumers' welfare. As a result, competition fosters efficient resource allocation by forcing suppliers to manage their operations tightly. Additionally, it promotes innovation among the business actors to realize more profit by outpacing its competitors. ${ }^{2}$

Competition can have both positive and negative impact on the business world, both to the business actors and the consumers. Economists say that competition in market mechanisms will stimulate business actors' innovation to produce a variety of products at competitive prices and will benefit both producers and consumers. ${ }^{3}$ In the situation of fair competition, consumers will have an advantage of given the various choices by the market with various quality and price. However, in the case of unfair competition, the practice of anti-competition practices such as collusion, market domination by one or several business actors, and tender conspiracy can disadvantage the consumers who are forced to pay more than they should. It is also injurious to business actors as the market mechanism is disorganized and controlled by only several powerful business actors, which can cause unhealthy business activities in the market.

As it has both positive and negative sides, business competition has to be regulated in a particular law. Without the existence of a sufficient law regarding Anti-Competition, the business world will be chaotic as there is no benchmark on what practices are allowed and what are not to be conducted for the development of the economy. Instead, business actors will all exert their power to control the market for their benefits without considering other business actors $^{4}$ or consumers. As an answer, the government issued Law No. 5 of 1999 on Prohibition of Monopolistic Practices and Unfair Business Competition (hereinafter referred to as "Law No. 5/1999") to manage the practices of business competition in Indonesia. To help the implementation, Indonesia's Business Competition Supervisory Commission (KPPU) was also established in 2000.

In the New Order Era, anti-competition practices were very pervasive, especially by the companies owned by the government or families of the government members. The prevalent practice of tender conspiracy was when big tender projects are done, the winner of the tender had been decided. In contrast, the tender offer was still formally conducted with some tender participants. This is supported by the fact that Indonesia, as a developing country, still needs a lot of infrastructure construction, both governmental and public, so there are so many projects that are offered through tender. Correspondingly, the companies, knowing that there was no regulation that prevented them from doing tender conspiracy practices, use the gap in the law to enrich themselves with this dishonest act.

Tender, as stated in the Elucidation of Article 22 of Law No. 5/1999, is explained as a bid to submit price quotations to acquire a specific contract work in order to procure goods or provide services. The prohibition of tender conspiracy is regulated in Article 22 of Law No. $5 / 1999$, which specifies that entrepreneurs are prohibited from conspiring with other parties to

2 Colin Hines, Localization: A Global Manifesto, Earthscan (Abingdon: Earthscan, 2013), https://doi.org/10.4324/9781315071381.

3 David Scherer, F.M and Ross, Industrial Market Structure and Economic Performance (Boston: Houngton Mifflin Company, 1990).

4 Ayup Suran Ningsih, Duhita Driyah Suprapti, and Nurul Fibrianti, "The Importance of Applying the Membership Value Toward Savings and Loans Cooperatives in Indonesia," Sriwijaya Law Review 3, no. 2 (2019): 225-34. 
determine the tender winner. Most of the tender conspiracy practices happen in governmental projects, in which big projects need significant procurement of goods/services. This causes tender to be frequently referred to as the procurement of goods/services itself.

Tender conspiracy gives injurious effect to the consumers because they will buy products with less quality or with a higher price, solely because of the conspiracy between the entrepreneurs. The purpose of the tender is to gain the best goods and/or services with high quality and low cost. However, tender conspiracy distorts that purpose by manipulating the situation and creating unhealthy business competition.

The practice of conspiracy in tender becomes a significant problem in the business competition world. Since the year of 2000 to $2016,70 \%$ of the business competition cases handled by KPPU are tender conspiracy cases, while the non-tender cases were numbered $30 \% .^{5}$ It shows that collusive tendering has been one of the most significant issues in business competition that is hard to control and to eradicate. The practice of tender conspiracy usually occurs in the tender project for a significant amount of purchase, including in governmental projects, which can lead to corruption and collusion.

The extensive and constant practice of tender conspiracy has a massive impact on the business competition in Indonesia. It is a harmful act, and therefore its excessive practice should be investigated further. For that reason, other than analyzing the prevailing regulation on tender conspiracy, the author will conduct research and analysis of a case regarding the tender conspiracy which dominates the court realm of KPPU. The case that will be analyzed is KPPU Decision No. 06/KPPU-L/2015 regarding the allegation of tender conspiracy practice among the tender participants and the tender committee in the project of Construction of DPRD Building of Barito Kuala District and its Land Development in the Budget Year of 2013-2015 (Multi years). The author would like to assess and investigate how tender conspiracy can happen in the business competition, how its elements prove that such practice has been done, and how KPPU applies its decision according to the provisions set out in Law No. 5/1999, as well as the legal consequence arising from such practice.

In response to the facts stated, two questions arise from the problems. The first is, how the regulation of tender conspiracy according to the Indonesian Competition Law is, which we aim to see how it is regulated, whether the law is already sufficient or not, and if there is weakness or gaps in the law that makes this violation easy to do. The second is how the KPPU Decision on a real tender conspiracy case adopted in this research is according to the law, in which we want to see how tender conspiracy is practiced and whether the decision is already in conformity with the law.

\section{RESEARCH METHODS}

To answer the problems above, the author will use normative law research, which emphasizes how the law defines the matter, as well as the legal norms that apply in society. Normative research derives information from the laws, government regulation, and other legal products using a normative law method. According to Peter Mahmud Marzuki whose research method only includes normative research, legal research is prescriptive instead of descriptive.

KPPU, "Statistik Penanganan Perkara KPPU," http://www.kppu.go.id/id/penegakan-hukum/statistik-perkara/ accessed on 20th February 2018. 
Descriptive research is appropriate if used in conducting social science research, while prescriptive research is the most suitable for legal research. ${ }^{6}$ Thus, the author will use the research method, as stated by Peter Mahmud Marzuki, which is normative in a prescriptive manner as this writing aims to assess the legal norms.

In this research, the author will use secondary data as the basis of the analysis, in which the author will analyze the quality of the law and other sources chosen, which categorizes it as qualitative research. ${ }^{7}$ The secondary data is obtained through literature. ${ }^{8}$ The author uses primary legal materials in forms of laws, Presidential Decrees, and KPPU Guidelines. The secondary legal materials used are books and journals, while the tertiary legal materials adopted are internet-based news, statistics, and law dictionary.

The author will use the statute approach and case approach. The statute approach will be conducted by examining and analyzing the relevant laws and regulations related to the formulated issues, ${ }^{9}$ in which the author will mainly use Law No. 5 of 1999 on Prohibition of Monopolistic Practices and Unfair Business Competition and KPPU Regulation No. 2 of 2010 on Guidelines on Article 22 Concerning the Prohibition of Tender Conspiracy (hereinafter referred as "KPPU Guidelines on Prohibition of Tender Conspiracy). The case approach will be conducted by analyzing the case of tender conspiracy which has been decided by KPPU with the case decision No. 06/KPPU-L/2015 regarding the Project of Construction of the Local House of Representative (DPRD) Building, District Barito Kuala, Kalimantan Selatan, and its Development in the Budget Year of 2013-2015 (Multi years).

As this is normative law research, the author will use the qualitative data analysis technique, as the author will analyze the information in the form of descriptions to come up with a specific conclusion that can be objectively accepted.

\section{ANALYSIS AND DISCUSSION}

\section{Regulation of Tender Conspiracy under Indonesian Competition Law}

\section{a. Concept of Tender Conspiracy}

Tender conspiracy, or usually called as bid rigging or collusive tendering is built of two significant concepts: tender and conspiracy. Elucidation of Article 22 of Law No. 5/1999 defines tender as a bid to submit price quotations to acquire a specific contract work in order to procure goods or provide services. KPPU gave a more detailed explanation that tender is an offer to submit the best price to do a particular job, to procure goods or provide services. ${ }^{10}$ The tender itself does not have a negative connotation; it is the opposite. Tender, as well as auction, has been used as a method to procure goods or services of the highest quality at the lowest price. In carrying out a fair tender process, the KPPU Guidelines on Prohibition of Tender Conspiracy clearly states the general principles of the tender, which include transparency,

\footnotetext{
Peter Machmud Marzuki, Penelitian Hukum (Jakarta: Kencana Pranada Media Group, 2009).

Meray Hendrik Mezak, "Jenis, Metode Dan Pendekatan Dalam Penelitian Hukum," Law Review V, no. 3 Maret (2006).

8 Yulianto Fajar, Mukti dan Achmad, Dualisme Penelitian Hukum-Normatif Dan Empiris (Yogyakarta: Pustaka Pelajar, 2015).

9 Marzuki, Penelitian Hukum.

10 KPPU, KPPU Guidelines on Prohibition of Tender Conspiracy (Indonesia: KPPU, 2010).
} 
appreciation of money, competent and open competition, fair negotiation, accountability in the assessment process, and non-discriminatory. ${ }^{11}$

Conspiracy, on the other hand, essentially gives a negative connotation. KPPU defines conspiracy as cooperation or collaboration done by the business actors with other parties upon anyone's initiative and to win a specific bidder. ${ }^{12}$ Article 1 number 8 Law No. 5/1999 defines business conspiracy as a cooperation of entrepreneurs to control the relevant market in the sole interest of the conspiring entrepreneurs. Responding to that, we can infer that conspiracy, which involves at least two parties whose final aim is to compete in an unhealthy manner, is a form of prohibited agreement, which pursuant to Article 1335 of Indonesian Civil Code, shall not have a binding effect, thus considered null and void. ${ }^{13}$ Additionally, looking from the criminal point of view, conspiracy is a vicious agreement that is regulated in Article 88 of the Indonesian Criminal Code. Conspiracy, not only in business competition, is generally viewed as an unlawful agreement that tends to create a negative outcome.

\section{b. Elements of Tender Conspiracy}

Tender conspiracy is regulated in Article 22 of Law No. 5/1999, which states:

"Entrepreneurs are prohibited from conspiring with other parties to arrange and/or determine the winner of the tender, thus causing unfair business competition."

From this article, some elements can be used to detect a tender conspiracy practice, such as ${ }^{14}$ :

1) There are Entrepreneurs (or Business Actors)

Entrepreneurs, as stated in Article 1(5) of Law No. 5/1999:

"Entrepreneur is a person or a company, in the form of a legal or non-legal entity established and domiciled or engaged in activities within the legal territory of the Republic of Indonesia, conducting various kinds of business activities in the economic sector through contracts, both individually or collectively."

The article mentioned defines entrepreneurs in a broad scope, which includes all entrepreneurs, individually or collectively, national or foreign, to be the subject of this provision. Additionally, it also covers business actors in government procurement as well as State-Owned Enterprises and private companies. Although matters of private companies are not injurious to the public but rather limited to the companies only, the practice of tender conspiracy itself embodies an unfair competition element that might distort the market, or the most direct, injures the private company as the buyer.

\section{2) To Conspire}

Conspiracy is the cooperation done by business actors with other parties at anyone's initiative in any way to win a specific tender participant. ${ }^{15}$ Conspiracy is the main element that creates a violation of healthy and fair competition. It is the inherent element that exists in corruption, collusion, and nepotism as well as cartel agreements, and in this case, in tender offers. In a

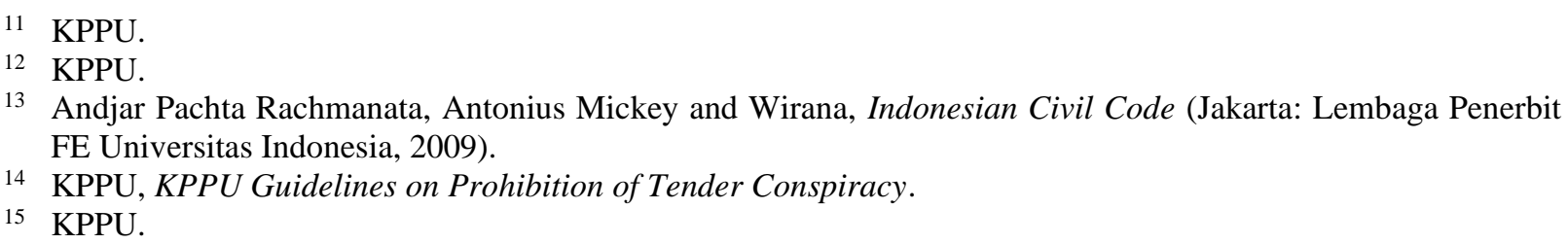


tender conspiracy that happens in government procurements, it is often that the tender participants - besides conspiring with one another - also conspire with the tender committee. With the cooperation of the committee, the tender process can seem to run strictly and formally, ${ }^{16}$ but behind those formalities, the committee has determined the winner, as has also been known by some participants who join in the conspiracy. The real tender agreement is done informally outside the office. ${ }^{17}$

\section{3) With Other Parties}

The regulation of tender conspiracy recognizes the element with other parties as an essential thing to be fulfilled for a tender conspiracy to happen. Since tender conspiracy is inherently an agreement, there has to be more than one party involved.

KPPU Guidelines on Prohibition of Tender Conspiracy defines the element of other parties as:

"The parties (vertical and horizontal) who are involved in the tender process which conducts tender conspiracy either as business actors as the tender participants or other legal subjects who are related to the tender."18

It means the term other parties in Article 22 refers to all parties who might have a role in causing or facilitating the practice of tender conspiracy, both in the horizontal and vertical framework. ${ }^{19}$ Thus it is not limited to business actors only, as what has been recognized in other countries, but also to third parties who join the collusion such as the tender committee or government officials. The aforementioned differentiates Indonesian competition law regulation regarding tender conspiracy from other countries, which only acknowledges tender conspiracy among business actors. Indonesia recognizes the involvement of vertical parties such as the tender committee as a violation of competition law. In contrast, collusion with the tender committee, government officials, or any parties who abuse their power for their interest, either material or non-material, is considered a crime in other countries. Law No. 5/1999, therefore, has a broad meaning of other parties, in which any legal subject, individual or legal entity, can be categorized as other parties. ${ }^{20}$

In a horizontal framework, the tender participants will conspire with their competitors, while in a vertical framework, the tender committee is involved. However, there is a dispute regarding the phrase other parties in Article 22 that is considered not clear enough, and a party claimed to the Constitutional Court to rectify or clarify the meaning of other parties in the articles concerning conspiracy. Constitutional Court Decision No. 85/PUU-XIV/2016 clarified that other parties refer to any parties related to the business actors, so it is not limited to business actors only. Thus it includes both horizontal and vertical conspiracy - as have been discussed earlier. Nonetheless, the Head of Experts Team of Apindo (Asosiasi Pengusaha Indonesia or Indonesia Entrepreneur Association), Sutrisno Iwantono, spoke on behalf of the

16 Udin Silalahi, Perusahaan Saling Mematikan \& Bersekongkol, Bagaimana Cara Memenangkan? (Jakarta: PT Elex Media Komputindo, 2007).

17 Silalahi.

18 KPPU, KPPU Guidelines on Prohibition of Tender Conspiracy.

19 Asmah, "Penerapan Sanksi Denda Terhadap Kasus Persekongkolang Tender Jalan Nasional," Jurnal Yudisial 12, no. 2 Agustus (2019), https://doi.org/http://dx.doi.org/10.29123/jy.v12i2.280.

20 KPPU, KPPU Guidelines on Prohibition of Tender Conspiracy. 
association that the other party in a tender conspiracy should only refer to the other business actors in the horizontal framework. In contrast, vertical conspiracy should fall under criminal jurisdiction. ${ }^{21}$ Hence, Apindo requested the Constitutional Court to give a more precise explanation regarding this phrase, so it does not create multi-interpretation.

4) To arrange and/or determine the Winner of the Tender

This element refers to the action of the parties involved in the tender conspiracy, which aims to eliminate other business actors as his competitors and/or to win a particular tender participant in various ways. The arrangement and/or determination of the winner of the tender is done through activities such as in determining the criteria for winners, technical requirements, financial, specifications, tender processes, and so on. ${ }^{22}$

\section{5) Causing Unfair Business Competition}

As stated in Article 1(6) of Law No. 5/1999:

"Unfair business competition is the competition among entrepreneurs in conducting their production activities and/or in marketing goods and/or services, conducted in a manner which is unfair or contradictory to the law or hampering business competition."

The primary purpose of the implementation of Law No. 5/1999 is to create a fair and proper business competitive situation and to create equal opportunity for the citizen of Indonesia to participate in the business activities in a healthy, effective, and efficient business climate. ${ }^{23}$ Placing this element as the concluding and final aspect of this article emphasizes the aim of this law as well as solidly classifying tender conspiracy as a banned activity which practice causes unfair business competition. Any tender conspiracy practice which causes unfair business competition shall be punished under the provisions according to this law.

\section{c. Methods of Tender Conspiracy}

Tender conspiracy can happen in many ways, as long as it involves the conspiracy of several parties to win a bid unfairly. Usually, tender conspiracy is characterized by determining the bid winner before the bidding process itself. Practically, there is no limitation of techniques to conduct tender conspiracy as it depends on the agreement between the conspiring parties. However, based on practices that have been done, there are several methods of tender conspiracy recognized from the patterns of the tender conspiracies that have happened.

Organization for Economic Co-operation and Development or OECD classifies four standard bid-rigging methods; ${ }^{24}$ cover bidding, bid suppression, bid rotation, and market allocation.

Cover bidding is the most commonly used method of tender conspiracy. This method is useful when an individual or company agrees to enter an offer that involves the factors of: a) the competitor agrees to enter a higher bid than the agreed tender winner's bid; b) the competi-

21 Tirto.id, “Apindo Minta KPPU Patuhi Putusan MK Soal Praktik Kartel,” n.d., https://tirto.id/apindo-mintakppu-patuhi-putusan-mk-soal-praktik-kartel-cxP9, accessed on 26 September 2018.

22 KPPU, KPPU Guidelines on Prohibition of Tender Conspiracy.

23 "Law Number 5 of 1999 Concerning the Prohibition of Monopolistic Practices and Unfair Business Competition" (1999).

24 OECD, "Pedoman Untuk Mengatasi Persekongkolan Tender Dalam Pengadaan Publik,” 2009. 
tor includes a bid that is known to be too high to accepted; or c) the competitors submit an offer that specifies a special condition known to be unacceptable to the buyer. This kind of conspiracy can create an illusion of a real, competitive, and fair tender process as it seems like the participant who offers the lowest price deserves to be the winner. However, the common practice shows that the price offered by the bid winner - by a very high chance - has been marked up. The margin from the real cost and the offered price will usually be shared as a compensation to the other participants joined in the conspiracy who have submitted losing bids. Often, the compensation was paid through a fake subcontracting or consultation bill. ${ }^{25}$ Cover bidding is often referred to as fake bidding, which displays the concept of the tender conspiracy that includes manipulation and prohibited agreement.

Bid suppression is a method which involves agreements among the competitors in which one or more bidders agree to refrain from bidding or withdraw a previously submitted bid in order to facilitate the designated bid winner to get the tender project. ${ }^{26}$ While bid rotation is when the competing companies conspire to make bids, but they agree to take turns to be the tender winner. Bid rotation is conceptually similar to arisan in which the conspiring companies agree to take turns to be the tender winner. There are various ways the conspiring companies can implement this scheme. For example, they can allocate approximately equal monetary values from a specific group of contracts to each firm or allocate volumes that correspond to the size of each company. ${ }^{27}$

The last is market allocation, which is indicated when competitors divide their markets and agree to cease competition based on their agreed geographical division. The specific company will hold the position of bid winner for a specific location and will not submit a competitive bid to another location. Sometimes this is effective regarding the companies' respective location, but this can be harmful to new competitors who will not get an absolute dominion over a specified location.

\section{d. Types of Tender Conspiracy}

In general, there are three types of Tender Conspiracy: ${ }^{28}$

1) Horizontal Tender Conspiracy

This conspiracy occurs between the tender participants or the bidders (figure 1). ${ }^{29}$ This conspiracy creates false competition between the tender participants. Horizontal tender conspiracy is essentially an illegal agreement amongst the competitors to not compete, instead to manipulate the competition to reap more benefit for themselves but, at the same time creating an illusion of fair competition. This type is the globally recognized type of collusive tendering or bid rigging and is theoretically more comfortable to be conducted because it only involves one side of the tender process, which is the participants' side.

\footnotetext{
25 Andi Fahmi et all Lubis, Hukum Persaingan Usaha, Edisi Kedu (Jakarta: Komisi Pengawas Persaingan Usaha, 2017).

26 OECD, "Pedoman Untuk Mengatasi Persekongkolan Tender Dalam Pengadaan Publik."

27 OECD.

28 Lubis, Hukum Persaingan Usaha.

29 Deni Marbun, Rocky dan Bram, Kamus Hukum Lengkap (Jakarta: Visimedia, 2012).
} 


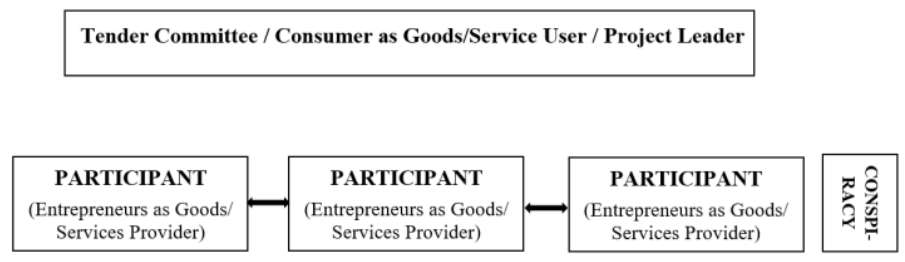

Figure 1. Horizontal Tender Conspiracy

Source: KPPU $(2010,7)$

\section{2) Vertical Tender Conspiracy}

This conspiracy occurs between one or several entrepreneurs as the bidders with the tender committee or auction committee or the user of the goods/services or the buyer (figure 2). The conspiracy happens where the tender or auction committee cooperates with one or several tender participants. ${ }^{30}$ Because the participants are not conspiring with one another, usually, the bid winner is the one favored by the tender or auction committee. This bid winner is usually the one who offers the most significant fee to share to the committee if they win the bid.

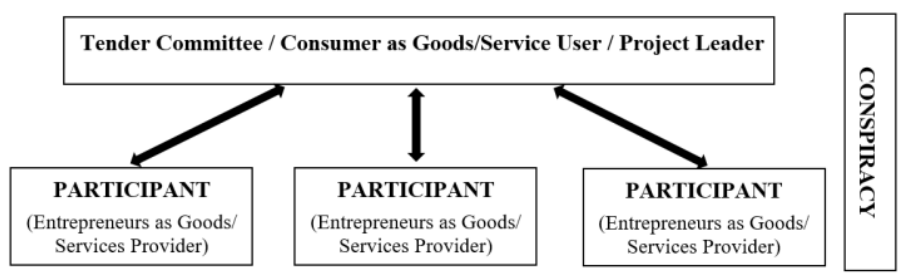

Figure 2. Vertical Tender Conspiracy.

Source: KPPU $(2010,8)$

3) Integrated Tender Conspiracy (Horizontal and Vertical)

It occurs when there are multiple conspiracies between the parties in the tender. The conspiracy can happen between the tender or auction committee with the user of goods/services or the buyer with the tender participants (figure 3). One of the examples of integrated tender conspiracy is fictitious tender in which the tender process is done only in an administrative and closed manner. ${ }^{31}$ In concept, this type of conspiracy is a mix between horizontal and vertical conspiracy.

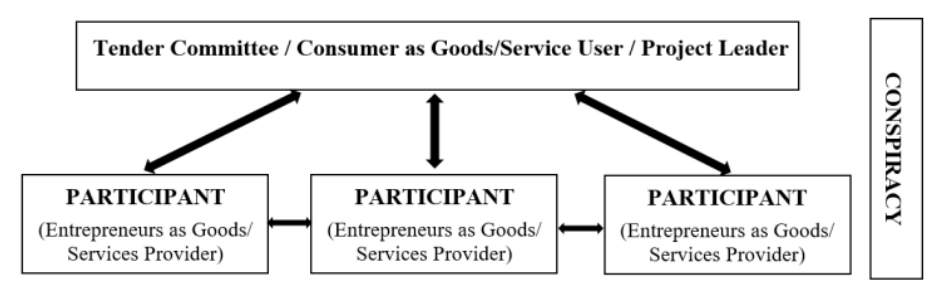

Figure 2. Integrated Tender Conspiracy.

Source: KPPU $(2010,8)$

30 KPPU, KPPU Guidelines on Prohibition of Tender Conspiracy.
31 KPPU. 


\section{e. The approach used to Detect Tender Conspiracy}

Tender Conspiracy, as regulated in Article 22 of Law No. 5/1999, uses Rule of Reason Approach to detect whether the conspiracy has done causes injury to the competition or not. Rule of the reason is a doctrine built based on the interpretation of the Sherman Antitrust Act by the Supreme Court of the United States of America, which was applied in the case of Standard Oil Co. of New Jersey vs. the United States in 1911. According to this doctrine, only the combinations and contracts that unnaturally disrupts trade that is subject to the restrictions of antitrust law and the control of monopoly power are not necessarily illegal. ${ }^{32}$ This approach gives room for interpretation of the court to consider the competitive factors and trade barriers resulting from the allegedly antitrust acts, whether it interferes, influences, or even obstruct competition process. ${ }^{33}$

One of the main characteristics of the rule of reason approach is using economic analysis to achieve efficiency to know the implication of business actors' activities to the competition. ${ }^{34}$ KPPU has to prove whether the tender conspiracy has a negative or rather positive effect. If the conspiracy does not disadvantage the consumers and does not disturb the competition, then it is not punishable under the article mentioned. However, in practice, tender conspiracy is almost always injurious, especially in government procurement, both to the public whose tax money was misused and to the other competitors who loses the bid just because of collusion to win a particular party. That is why tender conspiracy is viewed as a deep-seated barrier of competition; because it injures the business competition, the state, and the people. Moreover, repeatedly mentioning that tender conspiracy is a hardcore cartel, which should be regarded as a per se restriction of competition, as has been applied by the countries of the European Union and embodied in Article 101(1) of the Treaty on the Functioning of the European Union. ${ }^{35}$ As a hardcore cartel, which has caused many injuries to many parties, the author thinks that it is more effective and efficient to use per se illegal approach, which does not require further investigation regarding the loss suffered.

In other countries, tender conspiracy or collusive tendering has been ruled with a per se illegal approach, and even considered as a criminal offense in some countries. ${ }^{36}$ In South Africa, all cartel conducts, including collusive tendering, market allocation, and price-fixing are criminally punishable for fines up to R500.000 (around Rp.500.000.000,00) and imprisonment for up to 10 years. Specifically for collusive tendering, The Prevention and Combating of Corrupt Activities Act of South Africa sees it as a form of corruption and provides sentences ranging from five years to life imprisonment for the conspiring parties. ${ }^{37}$ In the United States of America, Section 1 of the Sherman Act 1890, 15 U.S.C $\S 1$ criminalizes all agreements in restraint of trade, including tender conspiracy. Moreover, a California-based business law firm, Bona Law PC, mentions that bid-rigging is one of the most severe antitrust violations, as it has

32 KPPU, "The Guidelines of Article 15 (Closed Contracts) Law No. 5 Year 1999 on the Prohibition of Monopolistic Practices and Unfair Business Competition," (n.d.).

33 Lubis, Hukum Persaingan Usaha.

34 Lubis.

35 International Competition Network, “Anti-Cartel Enforcement Template,” 2015.

36 OECD, "Pedoman Untuk Mengatasi Persekongkolan Tender Dalam Pengadaan Publik."

37 BusinessTech, "Collusive Tendering and Price Fixing Will Land You in Jail for 10 Years," n.d. 
been designated as a per se antitrust violation by the court. ${ }^{38}$ In regards to the tender conspiracy that has been proven, criminal prosecution is applicable to both corporations and individuals. ${ }^{39}$

These countries, out of many others, include tender conspiracy and some other anticompetition practices that are harmful by essence as criminal offenses that are directly punishable without examination of injury felt by the public or the competitors due to the inherent nature of those cartel conducts that are harmful. From such a policy, we can infer that they apply per se illegal approach due to very reasonable circumstances that no benefit will come out of tender conspiracy. Moreover, hardcore cartels are the main target of KPPU, so tender conspiracies that cause damages to the competition can be handled better or even better, prevented.

In reality, out of all the four practices included as the hardcore cartel, only price-fixing is regulated with per se illegal approach in Law No. 5/1999. Following the considerations above, it will be more effective if the tender conspiracy is regulated by per se illegal approach to increase the effectiveness and efficiency in dealing with tender conspiracy allegations, as well as saving time and effort for not having to do an extensive investigation regarding the effects of the practice.

\section{The judgment of KPPU in KPPU Decision No. 06/KPPU-L/2015}

The case adopted in this research is KPPU Decision No. 06/KPPU-L/2015 regarding the allegation of the violation of Law No. 5/1999 concerning Tender for the Construction of the building of DPRD Kabupaten Barito Kuala, Kalimantan Selatan and its Land Development in the Budget Year of 2013-2015 (Multi years) (hereinafter referred as "tender project"). The project's total value of HPS ${ }^{40}$ of Rp.49.800.000.000,00 (forty-nine billion eight hundred million rupiahs), and the source of funding comes from APBD Fiscal Year 2013-2015 (Multi years). This case mainly revolves around the allegation of violation of Article 22 of Law No. 5/1999, which regulates the prohibition of tender conspiracy.

From the preliminary examination done by the investigators, there is an allegation of tender conspiracy done by the tender registrants of the project, namely:

PT Citra Kharisma Persada (Defendant I; hereinafter referred as "PT CKP”), PT Cempaka Mulia Perkasa (Defendant II; hereinafter "PT CMP"), PT Sumber Nor Abadi (Defendant III; hereinafter "PT SNA"), as well as Pokja I Bidang Cipta Karya Dinas Pekerjaan Umum Kabupaten Barito Kuala Tahun Anggaran 2013 (Defendant IV; hereinafter "Pokja") as the tender committee, and Pejabat Kuasa Pengguna Anggaran Bidang Cipta karya Dinas Pekerjaan

38 Bona Law PC, "Bid-Rigging Is a Per Se Violation of the Antitrust Law," https://www.theantitrustattorney.com/bid-rigging-per-se-violation-antitrust-laws/. Accessed on 2 October 2018.

39 Farrin Jones, Keith and Harrison, "Criminal Sanctions : An Overview of EU and National Case Law," March 2014, http://awa2015.concurrences.com/articles-awards/business-articles-awards/article/criminal-sanctions-anoverview-of-eu-and-national-case-law. accessed on 22 October 2018

40 The Government of Republic Indonesia, "Presidential Decree Number 16 of 2018 on Government Procurement of Goods/Services," (2018), https://jdih.lkpp.go.id/regulation/peraturan-presiden/peraturan-presiden-nomor-16tahun-2018. 
Umum Kabupaten Barito Kuala Tahun Anggaran 2013 (Defendant V; hereinafter "KPA") as the budget supervisor, due to the fact that the source of funds is from APBD.

The chronology of the tender conspiracy was initiated with the tender offer, which was announced through the website of the Tender of Construction of DPRD Building of Kabupaten Barito Kuala, including its land development. The methods used were post-qualification using the electronic platform www.lpse.baritokualakab.go.id. The announcement is made from $15^{\text {th }}$ to $23^{\text {rd }}$ of May 2015, and the tender winner will be announced on the $4^{\text {th }}$ of June 2015 . Based on these dates, the period is 11 to 19 days.

In order to prove the occurrence of the violation of Article 22 of Law No. 5/1999 regarding the tender conspiracy, in this case, we have to observe whether the Defendants concerned to fulfill the elements of Article 22 or not.

From the earlier discussion, there are five elements of Article 22, namely: (1) entrepreneurs; (2) to conspire; (3) with other parties; (4) to arrange and/or determine the winner of the tender; (5) and causing unfair business competition.

The first element of entrepreneurs are fulfilled by the legal status of PT CKP, PT CMP, and PT SNA as licensed and registered legal entities doing business in Indonesia. The companies themselves have been established for around ten years or more based on Indonesian law.

Regarding the second element to conspire, first of all, the KPPU Guidelines on Prohibition of Tender Conspiracy explains that there are three types of tender conspiracy, as has been discussed before, which consists of horizontal conspiracy, vertical conspiracy, and integrated (horizontal and vertical) conspiracy. In addition, KPPU defines conspiracy as cooperation or collaboration done by the business actors with other parties upon anyone's initiative and in anyways to win a particular bidder. ${ }^{41}$ For that reason, the conspiracy will be divided according to the parties involved.

In this case, there is both horizontal and vertical conspiracy. The horizontal conspiracy that occurred was shown by several indications, such as (1) the similarities in the documents and the IP address of the defendant companies; (2) there is allegation of affiliation (one control) among the defendants that violates the law; and (3) there is similarity of Equipment Support Letter and Offer Guarantee Letter with consecutive number from the same providers (CV Sumber Jaya, PT Asuransi Parolamas, PT. Nusantara Raya Mujur, PT. Nusantara Jaya Mix).

Regarding the first point, KPPU found several similarities both in substance and format, such as a) similarity in the lack of the word "pemberian" compared to the guidelines given by the tender committee; b) similarity in the Method of Implementation section in which the job description and font type of PT CKP and PT CMP are similar (although PT CMP used italic letters); c) similar description and mistake in the K3 document in the part of "4.Jaring pengaman" from letter c to e; and d) similarity of unit price offered by PT CKP and PT CMP in the budget plan. ${ }^{42}$

Responding to this, Defendant I admitted that the tender registration was done by a freelance professional providing such service, in which the task delegated included inputting

41 KPPU, KPPU Guidelines on Prohibition of Tender Conspiracy.

42 KPPU, KPPU Decision No. 06/KPPU-L/KPPU/2015 (n.d.). 
data and IP Address. This order was first given to Mr. Khaerul, who was explained that because of such tender, he should not receive any other tenderly; in order to avoid similar documents with other participants. However, Mr. Khaerul gave the job to Mr. Abdurrahman alias Mr. Aman. Defendant II also gives the duty of document submission and registration process to a third party through one of its staff, who gave the job to Mr. Aman as well. Moreover, Defendant III also asserted that the matters of registration and administration of the tender document is given to the third party, which can be similar to the one used by other companies. Thus, the similarity made is clearly the work of the third party and not a conspiracy. Mr. Isra Bin Rusli Darman, the President Director of PT SNA, admitted that the registration documents are handled by Mr. Aman (the same person who handles the documents of PT CKP and CMP). He also studies the Work Plan and Terms (RKS). However, the document, as investigated, is different from the documents of Defendant I and Defendant II. So, Mr. Aman handled the documents matter for the three defendant companies, as well as the submission, which is shown by the similarity of IP Address of PT CKP and PT CMP with the number of 125.160.55.11 accessed in the same day, which is on 23rd of May 2015. In relation to that, Mr. Aman, who carried the document management task, responded to the allegation. He admitted to uploading the data through Electronic Procurement Service System (LPSE) Marabahan, at around 22.00 23.00 WITA, which is outside of the working hour after given the permission and access key to enter the bidding room from H. Tajuddin. H. Tajuddin himself later clarified that LPSE only opens at work hour (9 AM - 5 PM), and the IP Address of the LPSE is 22._._-_. The collection of facts above shows that Mr. Aman uploaded the documents outside the LPSE, from the same computer, and at the relatively same time - showing the sign of concerted action of the companies.

In respect to these facts, KPPU assessed that the tender documents should be made by each tender participant in a professional manner and must not be made by a third party or freelancer because it has the potential to result in the similarity of tender offer documents for several companies because they are made by the same person. The similarities in bidding documents that have been admitted by Defendant I, Defendant II, and Defendant III and also acknowledged by Mr. Aman as the tender offer document maker is sufficient to prove that indeed Defendant I, II, III did a pseudo-competition by arranging and abetting for Defendant I to be the winner in Tender Project.

Regarding the affiliation between the defendant's company, KPPU found that there is a second position between the defendants, strengthened by the fact that Haji Rusli is legally a director both in PT CKP and PT CMP. Haji Rusli is the Director I in Defendant I company and Director IV in Defendant II company as written in their company documents. In Haji Rusli's defense, he stated that he had resigned three years before the case; however, the Defendant II company admitted to having not revised the document regardless of its importance. Regarding this matter, the author thinks that the change in Article of Association or other documents containing the Board of Directors is an important matter which should have been revised as soon as there are changes. The fact that Haji Rusli's name is still written, although it resigned three years ago, is suspicious; Haji Rusli might still really have a directorate position or, at the very least, can influence PT CMP to join in the conspiracy. In addition, there is a familial relationship between PT CKP and PT SNA, in which Mr. Isra (director of PT SNA) is Haji 
Rusli's biological son. PT SNA itself does not meet the requirements imposed, which indicates that its participation is only as of the complementary participant. Also, Mr. Isra stated that he did not know that his father, Haji Rusli, is a director in PT CKP - which is suspicious because he should have known about that information because of the familial relationship. Familial relations itself can be a pretty strong sign of conspiracy, which should have been carefully overseen by the authorities. Furthermore, PT CMP was absent in the last clarification/verification process, which is allegedly to facilitate PT CKP to be the tender winner. In the qualification evaluation, PT CKP was not the first winner; it was second to PT CMP who was absent from the last evaluation process, so PT CKP as the second winner replaces the position as the tender winner. PT CMP's excuse was because there was a problem related to the Business Entity Letter (SBU) with the Membership Card for the association of the National Construction Executing Association (KTA Gapensi); which is the main requirement for making the SBU) which PT CMP has to take care of. However, the author thinks that if PT CMP was really serious in participating in this tender offer, they would have been more cautious about fulfilling the requirements or at least send a representative to be present in the last clarification stage as they knew that they had a chance to win.

In regards to the indication of the similarity of Equipment Support Letter and Offer Guarantee Letter with consecutive number from the same providers (CV Sumber Jaya, PT Asuransi Parolamas, PT. Nusantara Raya Mujur, PT. Nusantara Jaya Mix), from the facts collected the similarity and the consecutive number of the letters are because the companies concerned are the sole provider of the services in the district. In fact, some of the other companies who participated in the same tender offer also asked for a support letter from the said providers. This indication, according to KPPU, is not a very strong sign of conspiracy because it is logical for the companies to request a support letter from the best and nearest service providers to reduce cost and increase efficiency.

Meanwhile, the vertical conspiracy involves other parties, in this case, the Pokja as Defendant IV and KPA as Defendant V. Apparently, Defendant I as the tender winner does not fulfill the Basic Ability for the HPS requirements and the qualification of some personnel. Defendant I's Basic Ability as calculated from $3 \mathrm{NPt}^{43}$ is only Rp.42.830.913.000,00 while the HPS is Rp.49.900.000.000,00. About the personnel, there is a conformity of the qualification of the personnel required, such as Site Development Director, that has to be minimum S1 of Civil Engineering. At the same time, that position in PT CKP's document is held by Tatiana Erlina, whose degree is $\mathrm{S} 1$ of Architecture. These are preliminary requirements that have to be met. However, Pokja did not eliminate the Defendant I in the first place and even made it the winner.

Furthermore, the Auditor team detected an extra payment of around 3.9 billion rupiahs to the tender winner. However, Pokja said that it did not know about that, and it is probably because of the addendum in the contract and fluctuation. At the same time, the author thinks this is an indication of extra money, which will be distributed as the conspiracy fee to the conspiring parties. The last is how Pokja has been careless in checking the similarities of the documents and affiliation between Defendant I, II, III with the excuse of being overwhelmed,

43 KPPU. 
and did not know to the extent that such indications can lead to conspiracy. On the other hand, Defendant V was negligent in supervising Pokja's performance but was not directly involved in the conspiracy.

Regarding the element of other parties, it has been fulfilled with the involvement of the defendant companies in the horizontal conspiracy and Pokja and KPA in the vertical conspiracy. Based on such statements, the element of other parties is fulfilled.

While the element of to arrange and/or determine the winner of the tender has been fulfilled from the fact that: a) there are cooperation and affiliation among Defendant I, Defendant II, and Defendant III proven from the similarity of documents; b) the negligence of Defendant IV in checking and clarifying the affiliation of Defendant I, Defendant II, and Defendant III, and the negligence in calculating the KD of PT CKP who should have been eliminated in the qualification stage - which shows that Defendant IV facilitates Defendant I to win the tender; c) Defendant II's absence in the clarification stage although it should have been the tender winner shows its dubious and questionable motive to participate in the tender; and d) the participation of Defendant III was only as a complementary participant from the beginning, showing that it does not have the experience required in the tender project and voluntarily yielded in the competition. Based on these indications, the element to arrange and/or determine the winner of the tender is fulfilled.

And the last element is causing unfair business competition. The tender conspiracy done among the tender participants with the tender committee has created unfair business competition because it is a dishonest, collusive, and unlawful act. From the mentioned facts, it can be conferred that: a) the act of Defendant I, Defendant II, Defendant III as discussed in the horizontal conspiracy is a dishonest act that obstructs business competition; b) the act of Defendant IV to facilitate the horizontal conspiracy done by Defendant I, Defendant II, Defendant III as discussed is an unlawful act that obstructs business competition; and c) The tender conspiracy done by the defendants in this case, which has been proven as horizontal and vertical conspiracy are dishonest and unlawful act, which obstructs even deprives competitive business and potentially cause state loss. All of these shows that the tender conspiracy that occurred harms the other tender participants as competitors who lost the opportunity to win through an unfair tender process. Based on the statements, the element of causing unfair business competition is fulfilled. That means Defendant I, II, III, and IV have violated Article 22 regarding the prohibition of tender conspiracy as all of its elements are fulfilled.

In response, KPPU ultimately imposed fines the Defendant I, II, and III. Article 47 paragraph (2) point $\mathrm{g}$ states that the fines imposed are in the range of minimum Rp.1.000.000.000,00 and maximum Rp.25.000.000.000,00. KPPU determined that the amount of the sanction imposed is $10 \%$ from the tender winner price and subtracted by $10 \%$ of tax, which equals to Rp.4.863.936.900,00. However, the decision stated that the defendants are obliged to pay for Rp.242.002.360,00 for Defendant I, Rp.121.001.180,00 for Defendant II, and Rp.40.333.726,00 for Defendant III with the total of only around 400 million; less than $10 \%$ of what should be.

In response to the amount imposed in the decision, author contends that it does not cover up the loss that has been experienced - not even the actual damage from the margin of the 
payment which has been mentioned before which costs about Rp.3.929.390.690 although this amount has been repaid by Defendant I. Author thinks the fines imposed is too low that it does not create a deterrent effect to the companies concerned. It is not following the KPPU Guidelines on Administrative Actions, which regulates the calculation method. In addition, KPPU only imposed administrative sanctions and not criminal or additional sanctions that would have given enough repressive effect to the defendants. This can trigger the repetition of conspiracy because the benefit acquired therefrom is a lot bigger than the penalty imposed.

\section{CONCLUSION}

From the issues raised and the facts collected, the conclusion that can be inferred is that Article 22 of Law No. 5/1999 is not yet sufficient to regulate the prohibition of tender conspiracy. In practice, it is complemented by KPPU Guidelines, but it is also not yet clear to regulate severe such matters. However, the guideline elaborates on an important topic on the scope of the other parties, which refers to anyone that can affect the tender, and not limited to entrepreneurs. Also, tender conspiracy as a hardcore cartel and deep-seated barrier uses the rule of reason approach.

Responding to those conclusions, due to the vagueness of the regulation of tender conspiracy, author recommends the authorities to make necessary amendments or clarification to the guideline and if possible the law, such as elucidation of the elements of the article or confirmation of indications as sufficient evidence, in order to clarify the prohibition of tender conspiracy, as well as socializing and applying it in practice with hope to decrease the practice of collusive tendering. In the meantime, the author also suggests the existing guideline to be socialized further to all parties involved in the tender process. Additionally, the author thinks that the rule of reason approach applied for this particular violation is not valid since tender conspiracy almost always creates harmful outcomes, as it is a hardcore cartel and a deep-seated barrier of competition. It is more effective if it uses per se illegal approach that automatically determines the conspiracy practice as a violation. Therefore, the author recommends revising the approach used to save time and money from investigating whether it is beneficial to the competition and public or not.

Regarding the second matter, based on the facts presented, KPPU decided that there is horizontal conspiracy among Defendant I, Defendant II, and Defendant III displayed through the affiliation among the companies shown in various indications such as the similarity in tender documents, similarity of IP Address, double position between Defendant I and II, familial relationship between Defendant I and III, similarity in tender documents, similarity of IP Address, and the absence of Defendant II as the originally first winner to facilitate Defendant I as the second winner to win the tender auction. In addition, there is also vertical conspiracy that involves Defendant IV as the tender committee through its so-called negligence that passes the bid winner who actually did not fulfill the KD and personnel requirements, neglects the apparent similarities and the factor of affiliation with other companies. Moreover, there was an overpayment to the bid winner that was not detected by Defendant IV. However, Defendant $\mathrm{V}$ was only negligent as it is not directly involved in the conspiracy.

Aside of the conspiring element, the other elements set out by Article 22 such as entrepreneurs, other parties, to arrange and/or determine the winner of the tender, and causing 
unfair business competition are also fulfilled as explained from the indications met - which means the Defendant I, II, III, and IV are guilty of conducting tender conspiracy. As all the elements of Article 22 are fulfilled, then it is proven legally and convincingly that the Defendants related are guilty of conducting a tender conspiracy. Thus, the KPPU Decision concerned is already in line with Law No. 5/1999, which punishes the defendants of tender conspiracy proven guilty through the indications assessed by KPPU. However, the amount of sanction imposed by KPPU to Defendant I, II, and III is not in accordance with Article 47 paragraph (2) point g of Law No. 5/1999 and the KPPU Guidelines on Administrative Actions and is very low compared to the loss that might have been suffered, thus does not seem to give enough deterrent effect that could cause them to repeat their same violation in the future.

As a recommendation, the improvement of the implementation of the law by authorized parties, such as the tender committees who are qualified in both knowledge and ethics, is necessary to make sure that the law is implemented well. Another critical point is to include an anti-collusion clause in the procurement document, like, the prohibition of affiliation, which can lead to conspiracy practice. This clause does not automatically exclude the companies with the indications but marks them to be scrutinized more carefully. If such clause was included in the procurement document, there is a bigger chance that the conspiracy among Defendant I, II, and III based on the affiliation would have been detected earlier - which would save a lot of time and cost because the tender could have been conducted fairly.

In regards to the penalties imposed to the entrepreneurs who committed tender conspiracy, instead of just administrative fines as imposed in this case KPPU can give greater sanction such as to suspend the company to join tender procurements for a certain period of time that will create a deterrent effect to the defendants to prevent them from repeating their violations and prevent other companies who might want to do such practice. Also, KPPU should impose the appropriate amount of sanctions calculated under the provisions of Article 47 paragraph (2) point $\mathrm{g}$ of Law No. 5/1999 and the KPPU Guidelines on Administrative Actions.

\section{REFERENCES}

Asmah. "Penerapan Sanksi Denda Terhadap Kasus Persekongkolang Tender Jalan Nasional." Jurnal Yudisial 12, no. 2 Agustus (2019). https://doi.org/http://dx.doi.org/10.29123/jy.v12i2.280.

BusinessTech. "Collusive Tendering and Price Fixing Will Land You in Jail for 10 Years," n.d.

Fajar, Mukti dan Achmad, Yulianto. Dualisme Penelitian Hukum-Normatif Dan Empiris. Yogyakarta: Pustaka Pelajar, 2015.

Hines, Colin. Localization: A Global Manifesto. Earthscan. Abingdon: Earthscan, 2013. https://doi.org/10.4324/9781315071381.

Indonesia, The Government of Republic. Presicential Decree on Government Procurement of Goods/Services, Pub. L. No. Presidential Decree Number 16 of 2018 (2018).

Jones, Keith and Harrison, Farrin. "Criminal Sanctions : An Overview of EU and National Case Law," 2014.

KPPU. KPPU Decision No. 06/KPPU-L/KPPU/2015 (n.d.). 
KPPU Guidelines on Prohibition of Tender Conspiracy. Indonesia: KPPU, 2010.

"Statistik Penanganan Perkara KPPU," n.d.

The Guidelines of Article 15 (Closed Contracts) Law No. 5 Year 1999 on the Prohibition of Monopolistic Practices and Unfair Business Competition, (n.d.).

Law Number 5 of 1999 concerning Prohibition of Monopolistic Practices and Unfair Business Competition (1999).

Lubis, Andi Fahmi et all. Hukum Persaingan Usaha. Edisi Kedu. Jakarta: Komisi Pengawas Persaingan Usaha, 2017.

Marbun, Rocky dan Bram, Deni. Kamus Hukum Lengkap. Jakarta: Visimedia, 2012.

Marzuki, Peter Machmud. Penelitian Hukum. Jakarta: Kencana Pranada Media Group, 2009.

Mezak, Meray Hendrik. "Jenis, Metode Dan Pendekatan Dalam Penelitian Hukum." Law Review V, no. 3 Maret (2006).

Network, International Competition. “Anti-Cartel Enforcement Template,” 2015.

Ningsih, Ayup Suran, Duhita Driyah Suprapti, and Nurul Fibrianti. "The Importance of Applying the Membership Value Toward Savings and Loans Cooperatives in Indonesia." Sriwijaya Law Review 3, no. 2 (2019): 225-34.

OECD. "Pedoman Untuk Mengatasi Persekongkolan Tender Dalam Pengadaan Publik," 2009.

PC, Bona Law. "Bid-Rigging Is a Per Se Violation of the Antitrust Law," n.d.

Rachmanata, Antonius Mickey and Wirana, Andjar Pachta. Indonesian Civil Code. Jakarta: Lembaga Penerbit FE Universitas Indonesia, 2009.

Scherer, F.M and Ross, David. Industrial Market Structure and Economic Performance. Boston: Houngton Mifflin Company, 1990.

Silalahi, Udin. Perusahaan Saling Mematikan \& Bersekongkol, Bagaimana Cara Memenangkan? Jakarta: PT Elex Media Komputindo, 2007.

Siswanto, Arie. Hukum Persaingan Usaha. Jakarta: Ghalia Indonesia, 2002.

Tirto.id. “Apindo Minta KPPU Patuhi Putusan MK Soal Praktik Kartel,” n.d. 